\title{
LAW, ECONOMICS AND THE DRAFT TAKEOVERS CODE
}

\author{
Bob Dugan*
}

In August 1995, the Government announced that it would defer a decision whether to adopt the draft Takeovers Code that had been formulated and recommended by the Takeovers Panel pursuant to section 19 of the Takeovers Act 1993. This announcement culminates, at least for the time being, almost a decade of intense and sometimes acrimonious controversy over the regulation of takeovers in New Zealand. Economics-based arguments figured in the run up to the legislation, within the legislation itself, in the formulation of the Code and in the debate about its merits. After a review of the background and the principal features of the draft Code, this article considers the main issues in the law and economics debate that preceded the Government's decision.

\section{Background}

Takeover refers to a transfer of corporate control that is effected by means of an acquisition of shares from existing members and/or from the company itself. Until the 1970 's, at least in relation to listed companies, most control transfers proceeded by way of a merger or a purchase of assets. In the USA there were 29 cash tender offers in 1965 for companies listed on the New York Stock Exchange; in 1989 there were 139 tender offers reported under the Federal takeovers statute. ${ }^{1}$ The rise in takeovers is commonly attributed to a number of factors including the advent of new financing techniques, increased regulation of mergers and asset sales and the appearance of companies ripe for rationalisation. ${ }^{2}$

* Reader, Faculty of Law, Victoria University of Wellington. The author was employed as a researcher by the Takeovers Panel Advisory Committee and by the Takeovers Panel. The views expressed in this article are strictly personal to the author and do not purport to represent the position of the Panel.

1 The figures for 1966 were taken from Fleischer and Mundheim "Corporate Acquisitions by Tender Offer" (1967) 115 U Pennsylvania L Rev 317. The figure for 1989 was compiled from a search of the 14D-1 filings in the ACQUIS file in the COMPNY library on LEXIS (Meaddata Corp).

2 See Gilson "The Political Ecology of Takeovers" (1992) 61 Fordham L Rev 161. 
As both asset acquisitions and mergers are corporate transactions, they are subject to regulation by company law. Under the Companies Act 1993, both transactions require shareholder approval; any dissenting shareholder is entitled to have its shares taken up at a fair price. ${ }^{3}$ These rules represent the latest stage in the on-going evolution in company law, both here and overseas, towards the recognition of increased rights of participation and equal treatment for shareholders.

Unlike a merger or purchase of assets, a takeover is a securities transaction to which the company is not a party. As such, it lies outside the traditional scope of company law. Left unregulated, a takeover provides an acquisition vehicle that operates free of the rules applicable to mergers and asset purchases. A takeover can be effected without the cooperation of the target company's board of directors, approval from the target company's shareholders in general meeting or compliance with the minority buyout right. The acquirer needs to obtain only the approval, expressed by means of acceptance to its offer, from a sufficient number of shareholders to provide de facto control.

The first reaction to the regulatory gap occurred in the USA where the judiciary imposed a fiduciary obligation upon a seller of control. This obligation was breached, eg, by a sale to a suspected looter, a sale of corporate office or the diversion of a corporate opportunity. ${ }^{4}$ The Australian companies legislation in the early 1960's provided the first statutory regulation of takeovers. The statutes applied to any offer which would, if accepted, enable the offeror to control more than one third of the voting rights in a company. The statutes were pause and publicity measures designed to ensure that the offeree shareholders had ample time and information to make a reasoned decision. The statutes required the offer to be in writing, be left open for a minimum period of one month and be accompanied by specific information respecting the bidder and the target. ${ }^{5}$

New Zealand was the next jurisdiction to legislate for takeovers in the form of the Companies Amendment Act 1963, a pause and publicity regime similar to the Australian statutes. The Act exempts companies having 25 or fewer members where all members agree to waive the requirements of the statute or any case where offers are made to not more than six shareholders. The debates in the House reflect that Parliament intended the statute to apply, apart from the exempted cases, to all increases across and above the $20 \%$ threshold. ${ }^{6}$

3 Companies Act 1993, ss 106(1), 110, 112(1) and 129(2).

4 See R Clark Corporate Law (Little Brown, Boston, 1986) 478-498.

5 See Companies Act 1961 (Vic), s 184.

6 There is no mention in the debates that the statute is limited only to written offers. See Parliamentary Debates vol 336, 2017-2018; vol 337, 2654-2662. 
However, as drafted, the statute can be and was interpreted by the courts to apply only to written offers. ${ }^{7}$

Five years later, takeovers legislation was enacted in the USA. Like the Australian and New Zealand statutes, the Williams Act $1968^{8}$ comprises a pause and publicity regime. The statute employs a $5 \%$ threshold that, when compared to the higher thresholds in the Australian and New Zealand legislation, probably reflects the greater size and dispersion of holdings in USA companies. The Williams Act 1968 applies only to "tender offers", a term left undefined by the statute but one which has been interpreted by the courts to mean public offers for shares. ${ }^{9}$

In 1969, the London City Code on Take-overs and Mergers was promulgated. The City Code differs in three significant respects from the Australian, New Zealand and USA statutes. First, the City Code does not have the force of law. It is a code of conduct formulated by the London financial community to ward off takeover legislation. Breaches of the Code are punished by exclusion from the services of the financial community.

As its second notable feature, the City Code, while it includes the pause and publicity requirements found in the overseas enactments, has as its primary objective the equal treatment of shareholders. The core of the City Code is the mandatory offer rule. Any person who crosses the $30 \%$ threshold, whether by public tender or private acquisition, must make an offer to all shareholders of the target company. ${ }^{10}$ Further, the offer must be made on the same terms to all members of a class and at the highest price paid by the offeror for any securities acquired by it during the previous twelve months. ${ }^{11}$ The bidder may not take up any shares unless it receives acceptances sufficient to provide it with legal control. ${ }^{12}$ Partial offers, ie, ones for less than all of the outstanding shares, are permitted only with the approval of the Panel or with the consent of the target shareholders. ${ }^{13}$ Thirdly, the City Code prohibits defensive tactics. Only with shareholder consent may the directors of the target company take any action which could thwart a takeover. ${ }^{14}$

7 See Multiplex Industries Ltd v Speer [1966] NZLR 122 (CA).

815 USCA ss $78 \mathrm{~m}(\mathrm{~d}),(\mathrm{e}) ; 78 \mathrm{n}(\mathrm{d}),(\mathrm{e}),(\mathrm{f})$.

9 See Hanson Trust PLC v SCM Corp 774 F 2d 47 (2d Cir 1985).

10 City Code on Take-overs and Mergers 1990, rule 9.1.

11 Rules 16 and 9.5; General Principle 1.

12 Rule 9.3 and 10.

13 Rule 36.

14 Rule 21. 
The City Code has served as the model for subsequent takeover legislation outside the USA. Similar codes have been enacted by South Africa (1991), Malaysia (1987), Singapore (1985), and Hong Kong (1975). In 1981 Australia replaced its pause and publicity statute with a new enactment that clearly reflects the influence of the City Code. Under the Australian statute, a person may not move beyond the $20 \%$ threshold except by specified means, eg, by a written offer to all shareholders, by a stand in the market or by incremental acquisitions not exceeding 3\% every six months. ${ }^{15}$ The City Code has also been adopted as the model for the European Community's proposed Thirteenth Council Directive on Company Law.

The most recent takeover legislation is found in the state statutes in the USA. In 1987, the Supreme Court of the USA held that state autonomy over the internal governance of companies extends to regulation of takeovers so long as the state legislation does not interfere with the operation of the pause and publicity rules under the Williams Act $1968 .{ }^{16}$ Since then, over half the states have included takeovers provisions in their company statutes. These provisions typically require shareholder approval for any acquisition over a specified threshold (often 20\%), for the voting of any shares associated with such an increased holding or for a subsequent transaction between the target company and a successful bidder. ${ }^{17}$

Following enactment of the Companies Amendment Act 1963, the development of takeover regulation in New Zealand has been more controversial and tortuous than in other jurisdictions. In the 1970's the New Zealand Stock Exchange included in its Listing Rules a takeovers regime that shows the influence of the London City Code. The rules prohibited defensive tactics, provided for equal treatment of shareholders and required that the offer price be not less than the highest price paid by the bidder for target shares within the previous four months. ${ }^{18}$

In 1983, the New Zealand Securities Commission released a three-volume report that reviewed takeover practices in New Zealand and identified a number of perceived deficiencies in the existing law. The report noted that, due to the concentrated holdings of shares in New Zealand listed companies, takeovers were easily effected without compliance with the Companies Amendment Act 1963 under the exception for offers to less than six

15 See Corporations Law (Aust), ss 615-618.

16 CTS Corp v Dynamics Corp of America 481 US 69 (1987).

17 For a review of these statutes, see D Oesterle The Law of Mergers, Acquisitions and Reorganisations (West, St Paul, 1991) 414-460.

18 See Listing Requirements 1989, ss 9.4 and 9.5. 
shareholders or by means of offers not in writing. The report recommended adoption of takeovers legislation with the same salient features as the London City Code. ${ }^{19}$

Opposed by Treasury, ${ }^{20}$ the recommendations were never reduced to draft legislation. However, the Securities Commission was able to obtain enactment of the Securities Amendment Act 1988. That statute, which provides for the regulation of insider trading and the disclosure of substantial security interests, addresses two of the more serious problems arising in the context of takeovers.

In 1988, the Securities Commission released a second report and prepared a draft code. The report identified the equal treatment of shareholders as the proper basis for the regulation of takeovers. It criticised the Companies Amendment Act 1963 as an inept piece of legislation that induced discriminatory treatment of shareholders. ${ }^{21}$ The heart of the draft code was a mandatory offer rule with a 30\% threshold. Exceptions were provided for shareholder-approved transactions, market stands and certain allotments. The draft code, which met with heavy opposition from Treasury and various sectors of the business community, was never placed on the legislative agenda.

The Companies Bill 1990, the centre-piece of the Government's company law reform package, contained a single provision on takeovers. Clause 336, which applied to offers across or above the $20 \%$ level, required a thirty day minimum offer period, scaling in the event of over-subscription and advice by the target company's board of directors. The provision was heavily criticised on the ground that, dealing with a matter of securities law, it was outside the scope of the new companies statute.

While the Companies Bill was before Select Committee, which would eventually delete the clause on takeovers, the Government introduced the Takeovers Bill in December 1991. That Bill provided for the regulation of takeovers through secondary legislation. The Bill established a Takeovers Panel and delegated to the Panel the formulation of a takeovers code. The Governor-General was given the power to make regulations prescribing offences for breach of the code. The Bill required the Panel, in formulating the code, to consider specific objectives (eg, contestability of control and fair treatment of shareholders) and

19 Company Takeovers-A Review of the Law and Practice (Securities Commission, Wellington, 1983) vol 1, 10-16, 110-119.

20 "Takeovers are Good for Economic Efficiency" New Zealand Herald 7 May 1989, 1.

21 Company Takeovers-Report to the Minister of Justice (Securities Commission, Wellington, 1988) vol 1, 139. 
specific regulatory measures (eg, equal treatment of shareholders and regulation of defensive tactics). ${ }^{22}$

In November 1991, before introduction of the Takeovers Bill, the Government appointed the Takeovers Panel Advisory Committee. This committee was charged with the formulation of a draft takeovers code which, upon enactment of the Takeovers Act and the appointment of the Panel, could be adopted by the Panel as the takeovers code. ${ }^{23}$ The seven member committee comprised two commercial lawyers, two merchant bankers, an investment manager, a company director and an economist. ${ }^{24}$

In early 1992, the Advisory Committee considered an initial round of submissions on the specific measures identified in the Bill. At the same time, the Justice and Law Reform Select Committee was receiving submissions on the Takeovers Bill itself. A substantial majority of submissions to the Advisory Committee favoured a code that provided for an increased measure of participation and equal treatment for target shareholders. The submissions to the Select Committee were primarily concerned with the Bill's delegation of legislative authority.

After reviewing the submissions and academic literature, the Advisory Committee proceeded to formulate a draft takeovers code. At the same time, the Advisory Committee recommended to the Select Committee enforcement measures to be included in the takeovers statute. In April 1993, the Select Committee reported back the Takeovers Bill with new enforcement provisions, and the Advisory Committee released the draft takeovers code for public comment. The April 1993 draft was supported by a substantial majority of the submissions received by the Advisory Committee. It was opposed as uneconomic and unnecessary by the same parties which had opposed takeovers regulation for the last decade. In mid-September 1993, shortly before enactment of the companies law reform package including the Takeovers Act 1993, the Government announced that it was deferring

22 Section 20(1) requires the Panel to consider as objectives: the efficient allocation of resources, competition for control, the fair treatment of shareholders, the international competitiveness of the country's capital markets, shareholder choice, and the costs and benefits of compliance. Section 21 requires the Panel to consider, as regulatory measures, whether the code should provide for: advance notice and publicity, full information for shareholders and the target company, equal treatment of shareholders, incremental acquisitions, pricing rules, compulsory acquisition and defensive tactics.

23 Section 27 of the Takeovers Act 1993 provides that action taken by the Committee shall be treated as action taken by the Panel under the Act.

24 "Graham Names Members of Takeover Panel" National Business Review 29 November 1991, 45. 
a decision on the Code pending experience with the new companies statute and listing requirements. ${ }^{25}$

In December 1993, the Advisory Committee released the final version of the draft code which was identical to the April draft except for a number of technical amendments recommended by the submissions. At year end 1993, New Zealand had a new takeovers statute and draft takeovers code. However, before the Code could become law, the Takeovers Act 1993 had to come into force on 1 July 1994. Then the Minister had to appoint the Panel, the Panel had to recommend the Code to the Minister and the Minister had to advise the Governor-General.

In the first half of 1994, the Stock Exchange formulated revised Listing Rules that included a new regime for takeovers. This regime applies to a restricted transfer, ie, any increase in voting rights across the $20 \%$ threshold or any increase above that level greater than $5 \%$ pa. ${ }^{26}$ The Stock Exchange's previous takeover regime was mandatory, ie, consisted of rules applicable to any party to the listing agreement. In contrast, the new takeover regime applies, to a significant extent, on an opt-in basis. It comprises provisions, some of which must be incorporated in the constitution of a listed company and others which may but need not be incorporated.

The compulsory provisions include notice and pause requirements, enforcement provisions (eg, forfeiture of shares) and a compulsory acquisition scheme. ${ }^{27}$ The principal optional provision is the so-called minority veto regime pursuant to which a restricted transfer cannot be effected without an offer to all shareholders at the same price. ${ }^{28}$ This is the obvious counterpart to the fundamental rule of the draft Takeovers Code and the mandatory offer requirement of the City Code regimes.

In October 1994, after the new companies statute and listing requirements had been in force for only a few months, the Government appointed the Takeovers Panel. With three exceptions, the Panel consisted of members of the Advisory Committee. The Panel convened in late 1994 with a view to recommending a takeovers code to the Government. The Panel considered the December 1993 draft Code in view of the Companies Act 1993, the new Listing Rules and transactions in the New Zealand market during the period February 1993

25 "Controversial Takeovers Code Goes into Limbo" National Business Review 17 September 1993, 62; "Delay with Reform and Takeovers Code Out" New Zealand Herald 15 September 1993, 1.

26 Listing Rules 1994, rule 4.1.1.

27 Rule 4.3.1; the company may elect a notice and pause regime applicable to all restricted transfers or an alternative one applicable only to restricted transfers involving insiders. 
to April 1995. With one dissenting vote, ${ }^{29}$ the Panel decided that the draft Code should be recommended to the Minister without any modifications. In June 1995, the Panel sent the draft Code and accompanying report to the Minister pursuant to section 19 of the Takeovers Act 1993.

The appointment of the Panel rekindled the public debate over the regulation of takeovers in New Zealand. Supporters and opponents of the draft Code lobbied the government and conducted a vigorous debate in the media. In the end, the opponents of regulation again prevailed and on 10 August 1995, the Government announced its decision to defer action on the draft Code pending further experience with the new companies legislation and listing requirements. ${ }^{30}$

To date, only five listed companies have adopted the minority veto regime available under the Listing Rules. ${ }^{31}$ Opponents of the draft Code have cited this as evidence for absence of shareholder support for the Code. However, rejection of the minority veto regime more likely reflects the preference of a few large shareholders. Inclusion of this regime in a company's constitution requires approval by a special resolution of each affected interest group. There are two relevant interest groups, the one comprised of persons with holdings greater than $10 \%$ and the other comprised of persons with holdings of less than $10 \% .^{32}$ As the minority veto regime allows public shareholders to participate in the change of control and share in any premium, block holders may not perceive its adoption to be in their best interests. In all but 5 of the 142 companies listed in February 1995 , one block holder held sufficient shares to veto adoption of the minority veto regime.

It is understandable that a company like Fletcher Challenge, which has a large and diversified overseas membership, should adopt the minority veto regime. ${ }^{33}$ Overseas investors are accustomed to such protection under either City Code regimes or, in the USA, under company constitutions or statute takeover statutes. In the USA, recent studies indicate that provisions like those in the minority veto regime, whether imposed by statute or a company's constitution, result in a net increase in shareholder wealth. The wealth

29 "Takeover Trigger Queried" National Business Review 7 July 1995, 1.

30 "NZ Government Defers Decision on Takeovers Code" Reuters News Service-Australia and New Zealand 10 August 1995 from TXTANZ file in WORLD library on LEXIS (Meaddata Corp).

31 As of 17 January 1993, all but one of the listed companies had made the elections required by the Listing Rules; 98 had opted for the standard notice and pause regime, 19 for the insider notice and pause regime and 5 for the minority veto regime. See "Takeover Rules Leave Power NZ on Own" The Dominion 17 January 1993, 14.

32 Listing Rules 1994, rules 4.4.1 ["relevant group"] and 1.1.2 ["member of the public"].

33 "Fletcher Meeting Opts for Minority Regime" New Zealand Herald 31 October 1995. 
effect is thought to reflect the premium that the publicly owned shares will attract in the event of a takeover due to the participation rights secured by the minority veto clause. ${ }^{34}$

\section{Principal Features of the Draft Takeovers Code}

In formulating the draft Code, the Panel did not have an entirely free hand. The Takeovers Act 1993 requires that the Panel consider both specific objectives (eg, contestability of control and fair treatment of shareholders) as well as specific regulatory measures (eg, equal treatment of shareholders and regulation of defensive tactics). ${ }^{35}$ As there is considerable tension among the various objectives and measures, they effectively mandate a Code that advances each of the objectives in a balanced composite. This precludes a code that applies on an opt-in basis. As illustrated by the experience with the new Listing Rules, an opt-in regime cannot implement the fair treatment objective in relation to public shareholders. The vast majority of listed companies have one or more large shareholders who, even if they were not entitled to vote as a class, could generally thwart the adoption of any code which was perceived as a threat to their interests. Where, as under the Listing Rules, large shareholders are entitled to vote as a class, it appears unlikely that more than a handful of companies will ever approve such an optional regime. As its main thrust, the Code seeks to encourage competition for control and the same time to provide an increased measure of participation and equal treatment for shareholders. ${ }^{36}$

Fundamental rule. Clause 4, titled the fundamental rule, prohibits increases in voting rights across or above the $20 \%$ threshold except in compliance with the Code. This resembles the fundamental rule of the Australian takeovers statute. ${ }^{37}$ It is often characterised by opponents of the Code as a mandatory offer rule. However, this ignores the essential flexibility of the draft Code as compared to the City Code regimes.

The mandatory offer rule of the City Code imposes upon a person who crosses the threshold a positive obligation to make a full offer. In contrast, the fundamental rule of the draft Code does not impose a positive obligation. It is in the nature of a prohibition, ie, a person may not cross the threshold unless they proceed in a particular manner. The difference is not one of mere semantics. A person who inadvertently crosses the $30 \%$ threshold of the City Code is, in principle, required to make an offer for all the outstanding shares. Under the draft Code, if the acquisition breaches the fundamental rule, it does not follow that the person must make an offer to all shareholders. The breach can be remedied

34 See Comment and Schwert "Evidence on the Deterrence and Wealth Effects of Modern Antitakeover Measures" (1995) 39 J Fin Econ 3.

35 See summary list of objectives and measures above $n 22$. 
by a less extreme measure, eg, an order requiring the person to sell or not to vote the shares acquired in contravention of the fundamental rule.

One of the most frequent criticisms of the Code is that the threshold percentage is arbitrary or too low. Whilst the $20 \%$ trigger is the same as that in the Australian statute and the Companies Amendment Act 1963, it contrasts with the 30\% to 35\% thresholds found in the City Code regimes as well as the $5 \%$ threshold in the USA and the $10 \%$ in the federal Canadian statute. ${ }^{38}$

The trigger percentage reflects the objective of the particular regulatory scheme. The City Code regimes seek to ensure shareholders an opportunity to exit at a fair price once control has passed. Accordingly, the trigger percentage must be set slightly higher than the minimum holding thought necessary to confer control. The USA and Canadian statutes are pause and publicity regimes that provide shareholders adequate time and information for a reasoned decision on the merits of a public offer to purchase securities. The pause and publicity objective can be sensibly implemented at any level where the benefits of disclosure outweigh the costs. This is normally thought to occur in the USA at a level considerably below the minimum required to confer control.

The draft Code aims to allow shareholders an opportunity to participate in the transfer of control. Such an objective cannot be implemented unless the trigger percentage is set just somewhat below the minimum holding thought normally sufficient to pass control. It was the view of the Takeovers Panel that, in the New Zealand market, a holding less than $20 \%$ did not normally confer control, but a larger holding could, depending upon the distribution of shares in the particular company, suffice for de facto control. ${ }^{39}$ The Panel may also have been influenced by the use of a $20 \%$ threshold in the Australian statute in view of section 23 of the Takeovers Act 1993 that requires the Panel to have regard to the principles of CER.

The fundamental rule is also criticised as unnecessary in light of the experience in the USA. It is correct that the Williams Act 1968 regulates takeovers without an equivalent to either the mandatory offer rule in the City Code regimes or the fundamental prohibition in the Australian statute and draft Code. However, this criticism misconstrues the nature and extent of takeovers regulation in the USA. The Williams Act 1968 is only one component of the law applicable to takeovers in the USA. Of equal or regulatory significance are the state takeover statutes and the common law respecting defensive tactics and sale of control. Further, in the USA, the opportunity for exit and participation is partially secured by the wide dispersion of holdings in listed companies. In relation to most listed companies, the

38 City Code on Take-overs and Mergers 1990 (UK), rule 9.1 [30\%]; Code on Takeovers and Mergers 1992 (HK), rule 26.1 [35\%]; 15 USCA s 77n(d)(1) [5\%]; Canada Business Corporations Act 1985 (Can) s 194 ("take-over bid") [10\%].

39 See Report of the Panel on the Takeovers Code (8 June 1995) 10. 
prospective acquirer cannot gain control unless it makes an offer to all shareholders. In contrast, in New Zealand, three or fewer persons hold majority control in 88 of the 142 companies listed in February 1995; and in 113 of the companies, there was one shareholder who held at least $20 \%$ of the votes, which is often considered sufficient for de facto control. In New Zealand, a takeover is most often effected by means of an off-market acquisition of the one or two parcels that confer control. In such a market, participation by public shareholders in the transfer of control can only be secured by means of legislation.

Compliance options. The Code provides six ways for a person to increase its voting rights across and above the $20 \%$ level: ${ }^{40}$

- with the approval of a majority of disinterested shareholders;

- by an offer for all the outstanding shares (full offer);

- by an offer to all shareholders for less than all the outstanding shares (partial offer);

- by acquisitions in the $50 \%$ to $90 \%$ range at a maximum rate of $5 \%$ per annum;

- in any manner in the $90 \%$ to $100 \%$ range, subject to a two-way compulsory acquisition rule; or

- under an exemption from the Panel.

These compliance options are similar to those in the Australian statute. ${ }^{41}$ In the London City Code, there is no exception to the mandatory offer rule for shareholder approved acquisitions as opposed to allotments.

Where a person wishes to cross the $20 \%$ threshold, ie, move to de facto or de jure control, the person will ordinarily have to obtain shareholder approval or make an offer to all shareholders. The fundamental rule thus combines with the compliance options to provide all shareholders an opportunity to participate in a transfer of control, either by voting on the proposed acquisition or by accepting or rejecting an offer for their shares. This is the principal measure that the Code provides in response to the fairness objective in section 20(1)(c) of the Takeovers Act 1993. The participation rights are roughly comparable to those imposed by the Companies Act 1993 in relation to control transfers that are effected by means of mergers and asset acquisitions.

Opponents of the Code sometimes contend that there is no reasonable basis, legal or otherwise, for conditioning a member's disposition of its shares upon the involvement of the

40 For these compliance options, see draft Takeovers Code 1995, rules 5(1)(a) [shareholder approval], $4(1)$ and 6(1) [full offer], 4(1) and 7(1) [partial offer], 5(1)(b) [5\% incremental acquisitions], 5(1)(c) and 21 [increases above 90\%]; Takeovers Act 1993, s 45 [Panel's exemption power].

41 See Corporations Law (Aust), ss 623, 616, 635, 618, 615(1)(b) and 728. 
other shareholders, viz, by making them an offer or seeking their approval. However, there are numerous instances where company law and securities law require a third party's consent for a transaction between two other parties. The Listing Rules require shareholder approval for related party transactions and any allotment or buyback with control implications. ${ }^{42}$ The Companies Act 1993 requires approval for major transactions and amalgamations. ${ }^{43}$ Under the Securities Amendment Act 1988, board approval is required in order that share dealing by a director does not attract liability for insider trading. ${ }^{44}$ Whilst these rules are generally predicated on fairness considerations, leading academics have also found some of them to be efficient. ${ }^{45}$

Offer rules. Like its counterparts abroad, the draft Code prescribes rules for full and partial offers. These rules are designed to promote equality of participation and informed decisions. For hostile offers and ones for consolidation of control, they provide a transactional vehicle that generally follows current practices under the Companies Amendment Act 1963.

The same terms must be offered to all the holders of a given class of securities. A full offer must include all classes of voting and non-voting securities. The offer must remain open for not less than 30 days and not more than 90 days. The offer may be subject to conditions that are not dependent upon the judgement or control of the offeror. In the event of over-subscription to a partial offer, securities must be taken up on a pro rata basis. The offeror may not take up any shares unless it has received acceptances sufficient for majority control. Schedules to the draft Code prescribe the information that the offeror and the target company must furnish to the offeree shareholders. ${ }^{46}$

Unlike overseas regimes, the draft Code imposes no constraints upon the price paid for the securities, other than that the offeror must pay the same price for all shares subject to the

42 See Listing Rules 1995, rules 9.2.1 [transactions with related parties] and 7.5 [issues and buybacks affecting control].

43 Section 106(1).

44 Section 8(1) and Insider Trading (Approved Procedure for Company Officers) Notice 1993 , Schedule, Procedure I, cl 2(a); compare Companies Act 1993, s 145(3) [director's use of company information requires board approval].

45 See F Easterbrook and D Fischel The Economic Structure of Corporate Law (Harvard University Press, Cambridge, 1991) 171-174.

46 See rules 10 [same offer for all securities], 6(2) [comparable offer for securities in other classes], 13 [duration of offer period], 17 [conditions], 12 [scaling of excess acceptances], and 11 [minimum acceptance condition]. 
offer. ${ }^{47}$ The Panel was of the view that pricing rules linked to previous transactions represent an unnecessary interference with market forces and, in practice, serve only to impede the progress of a takeover. ${ }^{48}$

Prohibition on defensive tactics. The draft Code prohibits the directors from taking any action which could thwart the offer. This follows the approach of the City Code regimes and contrasts with the Australian and USA statutes which do not prohibit defensive tactics. $^{49}$

Shareholder autonomy. Like the Australian statute, the draft Code allows shareholders to waive the fundamental rule. Shareholders can also waive the minimum acceptance condition in relation to partial offers and the prohibition on defensive tactics in respect of specific transactions. ${ }^{50}$ Under the City Code, the target shareholders can waive the prohibition against defensive tactics and the mandatory offer rule in respect of allotments but not in respect of acquisitions. ${ }^{51}$

Compulsory acquisition. The draft Code adopts a modernised version of the two-way compulsory acquisition rule found in section 208 of the Companies Act 1955 as well as in the company statutes of other Commonwealth jurisdictions but not in the Companies Act 1993. Under that rule, once a person crosses the $90 \%$ threshold, it is entitled to and can be required to acquire the outstanding equity securities. ${ }^{52}$

There is nothing radical about the draft Code. The basic design of the Code as well as its specific features have been thoroughly tested in Australia and six City Code jurisdictions. The Code reflects a regulatory framework that is likely destined for adoption by the European Community. The philosophy, if not the detail, of this framework is consistent with the wave of state takeover legislation in the USA.

As their main objection, opponents argued that the Code would, without any recognised justification, increase the cost and reduce the frequency of takeovers to the detriment of the

47 Rule 10; compare City Code on Take-overs and Mergers 1990, rule 9.5 [highest price paid in preceding 12 months] and Corporations Law (Aust), s 641(1) [highest price paid in preceding 4 months].

48 See Report of the Panel on the Takeovers Code (8 June 1995) 10.

49 Rule 20; compare City Code on Take-overs and Mergers 1990, rule 21.

50 Rules 5(1), 7(2) and 20(1)(a).

51 City Code on Take-overs and Mergers 1990, rule 9, note 1 and Appendix 1 [whitewash guidance note].

52 Rule 21. 
New Zealand economy and shareholders. ${ }^{53}$ This objection can be expanded into five key propositions. (1) Takeovers are economically efficient, value enhancing transactions. (2) There is little academic support for the rules of the Code. (3) The Code will increase the cost of takeovers. (4) The Code will reduce the value of shares in listed companies. (5) The new companies statute and listing requirements deal adequately with any abuses arising from takeovers. The remainder of this article addresses these five propositions. The propositions regarding the efficiency of takeovers and academic support for the Code are discussed together by reference to the academic literature on takeovers.

\section{Regulation and Efficiency in the Literature}

The first discussions of takeovers in the academic literature appeared in the late 1960's in the USA, at about the same time that takeovers were gaining momentum as an acquisition vehicle. The most significant article during this period was probably the one by Professor Andrews in the Harvard Law Review. ${ }^{54}$ Andrews argued that, where a change of control is effected by a sale and purchase of shares, the acquirer should have to make a uniform offer to all members of the target company. Andrews based his argument on both fairness and economics. The proposed rule is fair in that it provides target shareholders with participation rights similar to those that they enjoy when control is transferred by means of a merger or an asset acquisition. The rule is efficient in that it deters uneconomic transfers without appreciably increasing the cost of economic ones. ${ }^{55}$

Andrews' article anticipated the adoption of the mandatory offer rule in the London City Code four years later. Today, after almost three decades of debate over the regulation of takeovers, Andrew's arguments remain the strongest ones in favour of the mandatory

53 See Wilkinson and Mandelbaum "The Takeover Debate in the Context of Securities Regulation in New Zealand: A Law and Economics Perspective" in Walker and Fisse (eds) Securities Regulation in Australia and New Zealand (Oxford, 1994) 808-811; "Roundtable Disputes Need for Code" The Dominion 12 July 1995, 17; "Call to Reject Takeovers Code" The Dominion 3 July 1995, 10.

54 Andrews "The Stockholder's Right to Equal Opportunity in the Sale of Shares" (1965) 78 Harvard L Rev 505.

55 In most cases, the proposed rule would require the would-be acquirer to purchase more shares than would be the case if the acquirer could deal only with the block holder(s). However, if the acquirer and its financial backers are confident of their ability to manage the business profitably, the cost of the additional shares will not deter the transaction. The acquirer will be able to finance the cost of the additional shares out of the dividends generated by those shares. In the case of uneconomic transfers of control, eg, where the acquirer intends to loot the company or is unsure of its ability to manage the business profitably, the cost of the additional shares will be a significant deterrent to completing the transaction. 
offer requirement in the City Code regimes and the fundamental rule in the draft Code. Andrew's position continues to receive support from leading academics in the USA. ${ }^{56}$

Most of the commentators during the late 1960's were concerned with the lack of symmetry between the regulation of public allotments and tender offers. ${ }^{57}$ In the case of an allotment, the securities law provided an orderly procedure and information basis for the investment decision. No similar safeguards attended the disinvestment decision associated with a takeover bid. At the time, bidders were free to proceed by way of "Saturday night special", viz., an offer open for a very limited period, accompanied by little or no information and available for acceptance on a first-come-first-served basis. Concern with the coercive nature of such offer tactics provided the academic support for the Williams Act 1968 , a pause and publicity statute not unlike that which had been enacted six years earlier in Australia.

Takeovers also caught the attention of financial economists, particularly those associated with the universities of Chicago and Rochester, who had been exploring the implications of the efficient market hypothesis. In the mid 1970's, there appeared a number of studies which analysed the share prices of companies involved in takeovers. These studies showed that takeover bids typically resulted in a $30 \%$ to $40 \%$ increase in the market price of the target company's shares. ${ }^{58}$ The price of the acquiring company's shares fared less spectacularly. On average, it showed little change or a slight decrease. Most studies concluded that the gains to target shareholders exceeded any losses to shareholders of the bidder.

The net gain to shareholders led many scholars to conclude that takeovers were a wealth-creating transaction. The studies provided an empirical and theoretical basis from which the liberal academics associated with the Chicago school of law and economics challenged the regulation of takeovers. In their 1981 article in the Harvard Law Review, Professors Easterbrook and Fischel argued that takeovers regulation should be limited to a prohibition on defensive tactics. ${ }^{59}$ In the same year, Professor Gilson took a similar

56 See most recently Elhauge "The Triggering Function of Sale of Control Doctrine" (1992) 59 U Chicago L Rev 1465.

57 Fleischer and Mundheim "Corporate Acquisitions by Tender Offer" (1967) 115 U Pennsylvania L Rev 317; Note "Regulation of Corporate Tender Offers under Federal Securities Law: A New Challenge for Rule 10b-5" (1966) 33 U Chicago L Rev 359; Sowards and Mofsky "Corporate Takeover Regulation: Gap in Federal Securities Regulation (1967) 41 St John's L Rev 499.

58 Dodd and Ruback "Tender Offers and Stockholder Returns" (1977) 5 J Fin Econ 351; for a survey of the literature, see Jensen and Ruback "The Market for Corporate Control: The Scientific Evidence" (1983) $11 \mathrm{~J}$ Fin Econ 5.

59 Easterbrook and Fischel "The Proper Role of a Target's Management in Responding to a Tender Offer" (1981) 94 Harvard L Rev 1161. 
position in the Stanford Law Review. ${ }^{60}$ These two articles probably remain the strongest academic challenge to takeovers regulation. It is interesting to note that, a year later, Professor Gilson parted company with Professors Easterbrook and Fischel on whether or not the law should facilitate competing tender offers. ${ }^{61}$

In the USA, the articles by Easterbrook and Fischel stimulated a further round of debate and research into the economics and regulation of takeovers. The anti-regulatory position was challenged on the ground that it rested on a simplistic view of value creation. The fact that I pay a premium over the market price for shares signifies only that, at the time of the purchase, I value the shares more highly than others in the market. Whether society's real wealth is increased depends upon my subsequent use of the shares, ie, whether I exercise the control conferred by the shares to increase the productivity of the company.

The premium can be viewed as a proxy for value creation if it represents a share of the anticipated profits from improved use of the target company's assets. One can identify many instances where a takeover leads to increased profitability of a previously lacklustre business. However, in other instances, the target company is a well managed, profitable business and experiences no improvements in its fortunes following the takeover. ${ }^{62}$ Numerous accounting studies of target companies show that, on average, takeovers result in no increase in profitability. ${ }^{63}$

Academics have identified, in theory and practice, at least seven possible explanations for takeovers and the associated premiums: ${ }^{64}$

(1) Improved management. The outsider identifies the target company as poorly managed. Confident that it can increase the company's profitability, the outsider is willing to pay a premium for a control parcel. The premium represents a share of the anticipated profits resulting from improved management.

60 Gilson "A Structural Approach to Corporations: The Case against Defensive Tactics in Tender Offers" (1981) 33 Stanford L Rev 819.

61 Gilson "Seeking Competitive Bids Versus Pure Passivity in Tender Offer Defense" (1982) 35 Stanford L Rev 51; Easterbrook and Fischel "Auctions and Sunk Costs in Tender Offers" (1982) 35 Stanford L Rev 1.

62 Servaes "Tobins Q and the Gains from Takeovers" (1991) 46 J Fin 409.

63 See, eg, Ravenscraft and Scherer Mergers, Sell-offs and Economic Efficiency (Brookings Institution, Washington, 1987). For a review of the literature, see Brous and Kini "A Reexamination of Analysts' Earnings Forecasts for Takeover Targets" (1993) 33 J Fin Econ 201.

64 For a summary, see D Oesterle The Law of Mergers, Acquisitions and Reorganisations (West Publishing, St Paul, 1991) 29-33. 
(2) Synergy. The outsider recognises that the target company possesses features which, when combined with those of the outsider, result in a entity that is more profitable than the two companies standing alone. The premium represents a share of the anticipated profits resulting from this synergy.

(3) Non-shareholder benefits. The outsider identifies the target company as a source of non-shareholder benefits, eg, the sale of assets or services to the company at over value. If the outsider can obtain control of the company by purchasing less than all of the shares, the potential for expropriation equals the value of the minority interests. Any premium paid for control represents a share of this anticipated expropriation. ${ }^{65}$

(4) Overpayment. Miscalculation, the "bidder's" curse or megalomania may lead the outsider to pay too much for the shares of the target company. It is overpayment in the sense that, even under optimal management, the target company would not provide an acceptable return on the investment. ${ }^{66}$

(5) Tax driven. Except for the operation of the tax law, some takeovers would not be economically viable. Many of the large takeovers in USA during the 1980's would not have occurred except for the availability of "junk bond" financing. These high return, high risk instruments owed their economic viability, in part, to the tax deductibility of interest payments. ${ }^{67}$ In New Zealand, the preferential treatment of capital gains has probably made securities acquisitions a more attractive investment in some cases than asset acquisitions. In a tax driven takeover, the premium reflects the anticipated tax benefit.

(6) Non-homogeneous demand. There is increasing evidence that the demand for listed securities resembles that for other assets. It is characterised by an inverse relationship between quantity and price. Under this view, there are many shareholders who value their holding higher than current market price. In order to amass a control block, the outsider must pay increasing amounts for each additional share. ${ }^{68}$

(7) Market inefficiency. A growing number of financial economists question the efficient market hypothesis. They believe that the share market does not always accurately reflect the value of shares. By means of research or good luck, the outsider can identify

65 See Barclay and Holderness "Private Benefits from Control of Public Corporations" (1989) 25 J Fin Econ 371.

66 See Black "Bidder Overpayment in Takeovers (1989) 41 Stanford L Rev 597.

67 Auerbach and Reishus "Taxes and the Merger Decision" in Coffee, Lowenstein and RoseAckerman (eds) Knights, Raiders and Targets (Oxford, New York, 1988) 300.

68 Stout "Are Takeover Premiums Really Premiums? Market Price, Fair Value and Corporate Law" (1990) 99 Yale L J 1235. 
under-priced securities. In paying a premium, the bidder divides with the target's shareholders the bargain element. ${ }^{69}$

In only the first and second explanations does the takeover premium serve as a proxy for wealth creation. In the other five explanations, the premium reflects a transfer or destruction of wealth rather than a creation of wealth. Whereas the first and second explanations warrant a hands-off policy towards takeovers, the remaining explanations justify various degrees of regulation. In the academic literature of the 1980's, one can find articles by prominent academics that advocate each of the key features of the draft Code including the equal price rule, the fundamental rule, the minimum acceptance condition, pause and publicity, prohibition of defensive tactics, exception for shareholder approved transactions and compulsory acquisition. ${ }^{70}$

Following the 1987 share market crash, there was a dramatic decrease in the number of takeovers and academic articles dealing with their regulation. In 1992, there were 36 tender offers filed under the Williams Act 1968 (USA) as compared with 138 in $1989 .{ }^{71}$ The number of articles in USA law journals about tender offers fell from around 100 in 1988 to around 10 in 1993. The regulation of takeovers last featured in a leading journal in 1989 when Professor Booth, writing in the California Law Review, argued for the repeal of the Williams Act $1968 .^{72}$ He concluded that legislation along the lines of the City Code or the state takeover statutes provided superior regulation.

This cursory review of the USA debate on takeovers regulation casts serious doubt on two of the principal propositions advanced by opponents of the draft Code, viz., that the rules of the Code lack academic support and that takeovers are value creating transactions. For every key feature of the Code one can find support in leading journals and tested precedent in overseas legislation. The law review articles in favour of regulation clearly outnumber those opposed to regulation. The case for regulation rests, ultimately, on

69 Kraakman "Taking Discounts Seriously: The Implications of 'Discounted' Share Prices as an Acquisition Motive" (1988) 88 Columbia L Rev 891 . These studies also cast doubt on the methodology of the share market studies, cited above $n 59$, which underlie the anti regulatory position.

70 Bebchuk "Toward Undistorted Choice and Equal Treatment in Corporate Takeovers" (1985) 98 Harvard L Rev 1695; Lowenstein "Pruning Deadwood in Hostile Takeovers: A Proposal for Legislation" (1983) Columbia L Rev 249; Coffee "Regulating the Market for Corporate Control: A Critical Assessment of the Tender Offer's Role in Corporate Governance" (1984) 84 Columbia L Rev 1145; Brudney, Equal Treatment of Shareholders in Corporate Distributions and Reorganisations (1983) 71 California L Rev 1072; Booth "The Problem with Federal Tender Offer Law" (1989) 77 California L Rev 707.

71 These figures were compiled from an examination of the 14D-1 filings found in the ACQUIS file in the COMPNY library on LEXIS (Meaddata Corp).

72 Booth "The Problem with Federal Tender Offer Law" (1989) 77 California L Rev 707. 
theoretical and empirical evidence respecting the efficiency of takeovers. Some takeovers create value, others destroy value and others transfer value. In this situation, the task of the lawmaker is to formulate regulation that facilitates economic takeovers and discourages uneconomic ones.

\section{The Draft Code and the Cost of Takeovers}

Opponents argue that the Code will increase the costs and thereby reduce the number of takeovers. This is a prediction about the operation of the Code in the New Zealand market. It cannot, unlike the propositions about the efficiency of takeovers and academic support for the draft Code, be verified by reference to the academic literature. Other jurisdictions have enacted codes similar to the draft Code and have share markets with a high degree of ownership concentration. Unfortunately, there is no academic literature regarding the operation of these codes and their effect upon the cost of takeovers. However, casual observers have noted that regimes more stringent that the draft Code do not appear to have unduly stifled economic activity or impeded takeovers in Australia and the City Code jurisdictions.

Nearly all of the academic studies of takeover regulation focus on the USA experience. In the USA the statutory framework and market conditions are very different from those in New Zealand. The Williams Act 1968 is a pause and publicity regime lacking the features, viz, the fundamental rule and minimum acceptance condition, which are said to make takeovers more expensive under the draft Code. State legislation in the USA regulates takeovers by more onerous rules some of which have no counterpart in the draft Code or City Code regimes. ${ }^{73}$ A recent study shows that this state legislation has not deterred takeovers. ${ }^{74}$

Also, listed companies in the USA are characterised by a much broader dispersion of share ownership than their New Zealand counterparts. Of the 142 companies listed in New Zealand in February 1994, 45 had one shareholder with more than $50 \%$ of the votes and 113 had at least one member with at least $20 \%$. In the USA, it is unusual to find a listed

73 See above $\mathrm{n} 17$ and accompanying text.

74 Comment and Schwert "Evidence on the Deterrence and Wealth Effects of Modern Antitakeover Measures" (1995) 39 J Fin Econ 3. 
company with a $20 \%$ shareholder. ${ }^{75}$ In the absence of relevant studies from overseas, the prediction about the cost effects of the draft Code must be considered solely against a careful reading of the Code and an analysis of its putative operation in the New Zealand market.

It is unquestionably true that, as applied to listed companies in New Zealand, the Code will interfere with the three most common techniques for acquiring corporate control through a purchase of shares. These are sometimes referred to as pass the parcel, creeping acquisition and dawn raid.

In a pass the parcel transaction, the acquirer gains de facto control or majority control by purchasing a single parcel of shares from the existing holder. Under the draft Code, such a transaction could proceed only with the approval of a disinterested majority of shareholders or under an exemption from the Panel. In the City Code regimes, a pass the parcel transaction triggers the mandatory offer rule and there is no exception for shareholder approved acquisitions.

In a creeping acquisition, the acquirer purchases one or more sub-control parcels and then, over an extended period, moves to de facto control by a combination of on-market and off-market transactions. The draft Code does not interfere with the acquisition of the subcontrol parcels so long as they do not push the acquirer over the $20 \%$ threshold. The effect of the draft Code upon incremental increases in the $20 \%$ to $50 \%$ range depends upon the nature of the acquisition. Increases through one-off acquisitions require shareholder approval or an exemption from the Panel. On-market acquisitions are possible only with the approval of the Panel.

In the dawn raid, the acquirer gains control by aggregating several sub-control parcels, usually from institutional investors. Whereas the creeping acquisition proceeds, at least in part, in public view, the dawn raid is usually notified to the market only once the deal is done. So as not to run afoul of the disclosure requirements of the Securities Amendment Act 1988 , the acquisitions must be put together over a short period, one measured in days rather than weeks. The draft Code would not interfere with increases up to the $20 \%$ threshold.

75 Companies registered under the Williams Act 1968 are required to report the holdings of directors, officers and principal (5\% or more) shareholders in their annual filings with the Securities Exchange Commission as well as in their proxy statements to shareholders. 15 USCA 78m(d)(1), (g)(1); 17 CFR 240.14a-3(a), 240.14a-101 item 6, 229.403(a). An examination of the proxy statements, as found in the PROXY file of the FEDSEC library on LEXIS (Meaddata Corp), filed by the top 30 (by sales) of the 1993 Fortune 500 companies showed that in 1995 only one company had a shareholder with more than $20 \% ; 15$ of the companies had no member with more than $5 \%$; and in the other 14 companies there were 11 persons with holdings in the $5 \%$ to $10 \%$ range and; 7 persons in the $10 \%$ to $20 \%$ range 
Further acquisitions from specific persons would require shareholder approval or the consent of the Panel.

Again, there is no question but that the draft Code would interfere with these three common acquisition techniques. However, as noted earlier, some takeovers create value, others destroy value and others merely transfer value. The salient issue is not whether the draft Code interferes with takeovers generally but whether it deters uneconomic takeovers and facilitates, or at least does not impede, economic ones.

The Panel identified, in relation to the period February 1993 to April 1995, 65 transactions that would have triggered the fundamental rule. ${ }^{76}$ One can only guess whether and how these transactions would have been implemented if the draft Code had been in force. However, it seems that most of the pass the parcel transactions could have proceeded under the Code's compliance option for shareholder approved transactions. About one third of them did not carry a premium and would not likely have been of concern to the shareholders. In the premium transactions, approval would have been forthcoming where the acquirer could convince the shareholders that it was bringing new value to the business in the form of synergy, a capital infusion or improved management. The only additional cost imposed by the Code would be the cost of putting before shareholders the motion and information required by the Code. Such transaction costs have not attracted criticism in other contexts. Shareholders routinely approve control transactions and related party transactions under the Stock Exchange rules ${ }^{77}$ even though the transaction may benefit a particular shareholder. Shareholder voting on fundamental corporate changes is commonly viewed as a cost effective monitoring device. ${ }^{78}$ Shareholders will balk at approving transactions which they perceive will bring nothing to the business. But those are the transfers of control that are least likely to be economic.

These same considerations also apply to dawn raids and creeping acquisitions to the extent that they entail purchases from specific individuals. Shareholders will approve such acquisitions, even though they may carry a premium, whenever they are perceived to be in the best interests of the company. Where the shareholders cannot be persuaded to approve the purchase, the transfer of control will be thwarted by the Code at least in the form of a dawn raid or creeping acquisition. If the would be acquirer wishes to proceed, it must make an offer to all shareholders. This will, in some cases, be a more expensive alternative than

76 See Report of the Panel on the Takeovers Code (8 June 1995) 3.

77 See Listing Rules 1995, rules 9.2.1 [transactions with related parties] and 7.5 [issues and buybacks affecting control].

78 See F Easterbrook and D Fischel The Economic Structure of Corporate Law (Harvard University Press, Cambridge, 1991) 79-80. 
the dawn raid or creeping acquisition. ${ }^{79}$ However, the fact or prospect of shareholder disapproval indicates there may be reason to question the economics of the proposed transfer of control.

Whilst the series of acquisitions used in dawn raids can proceed under the Code's provision for shareholder approved transactions, compliance with these provisions will preclude the stealth presently associated with this particular acquisition technique. However, it is questionable whether the economic benefits of stealth outweigh the benefits associated with monitoring function served by shareholder approval requirements.

Whereas specific acquisitions can be approved by shareholders, on-market purchases are possible only with the approval of the Panel. Other takeovers regimes make greater allowance for market purchases. For example, in the City Code regimes, market acquisitions immediately above the trigger threshold can be implemented under the provision for incremental increases, eg, not exceeding $2 \%$ pa under the London City Code. ${ }^{80}$ Under the Australian statute, market purchases are possible during the takeover period in an unconditional written offer, under a statutory procedure for market stands or as incremental increases not exceeding $3 \%$ every six months immediately a person crosses the $20 \%$ threshold. ${ }^{81}$

The draft Code's restriction on market purchases may have prevented a number of recent creeping acquisitions. However, this alone is not a reason for condemning the restriction. One must consider the alternative acquisition vehicles, the nature of the acquisitions affected by the restriction as well as the other benefits, if any, conferred by the restriction. In most cases, the draft Code's provision for partial offers will enable the acquirer to obtain majority control with less delay and at lower cost than the overseas provisions for incremental increases. For example, under the draft Code, a 33\% holder can increase to $51 \%$ by means of a partial offer for $27 \%$ of the outstanding shares. Under the London City Code, the $33 \%$ holder would have to creep to $51 \%$ over a number of years, make a full offer or seek shareholder approval for a $27 \%$ partial offer. In Australia, partial offers are impracticable due to the proportionality requirement. ${ }^{82}$

Of the three acquisition techniques employed in the local market, creeping acquisitions have probably been most heavily criticised on economic grounds, as they frequently appear to be speculative in nature. Upon reaching de facto control, the acquirer does not assume management of the target company. Instead, it sells the holding to a third person. The draft

79 See above $n 55$.

80 Rule 9.1(b).

81 Corporation Law (Aust), ss 620, 616, 674 and 618(1).

82 Corporation Law (Aust), s 635(b). 
Code does not prevent speculation. A person is free to acquire shares over the market up to the $20 \%$ level. Speculators are also free to secure a holding by means of a Code offer to all shareholders. In the USA, though the law does not so require, speculators frequently use the full cash offer and others make fortunes from arbitrage.

As its primary benefit, the restriction on market purchases may increase the contestability of a significant number of companies. Of the 142 companies listed as of February 1995, 69 were under the de facto control of a single person holding a $20 \%-50 \%$ parcel of shares. Under existing law and practice, that person can defeat a bid for control, whether in the form of a general offer or aggregation of sub-control parcels, by standing in the market for an additional $5 \%$ to $10 \%$ of the shares in the company. ${ }^{83}$ The de facto controller can afford to pay a price for a relatively small number of shares that the competing bidder cannot match in relation to the much larger number of shares subject to its general offer.

The Code's prohibition of market stands in the $20 \%$ to $50 \%$ range places the de facto controller on a level playing field with the outside bidder. If the de facto controller wishes to increase its holding, it must, like the outsider, obtain shareholder approval or make a Code offer open to all shareholders. So while the restriction on market increases raises the cost of creeping acquisitions, it will facilitate other takeovers. As firms subject to de facto control far out number those with open registers subject to creeping acquisitions, it is reasonable to conclude that the restriction would result in a net increase in takeovers.

Presumably in reference to this restriction, opponents have suggested that the Code will encourage an auction for control. Auctions are opposed on the ground that they will increase the costs of takeovers and reduce rather than encourage competition in the market for corporate control. This argument confuses auctions with increased contestability. The Code simply makes possible a bid for control in cases where, under existing law, the existing controller enjoys an insuperable advantage. An auction anticipates two or more concurrent bids for the same firm. The Code lacks those features which, in other takeover regimes, are thought to encourage auctions. For example, in contrast to USA law, the Code does not allow target shareholders to withdraw their acceptances or target directors to

83 For example, in December 1994 , the de facto controller of Mt Cavendish Gondola Ltd with 30\% of the shares thwarted Shotover Jet Ltd's general offer by standing in the market for an additional $10 \%$ of the shares. See "Aborted Bid and Bullish Valuation Divide Mt Cavendish Board" Independent 9 December 1994, 43. 
take measures promoting an auction. ${ }^{84}$ In any event, it should be noted that academics are divided over the economic efficiency of auctions for control. ${ }^{85}$

There are two other features of the Code that will facilitate takeovers. The first is the Code's prohibition of defensive tactics. Under existing law, the directors of a target company can take a number of measures to frustrate a hostile bid for control. For example, they can arrange for an issue of shares to a friendly third party, sell a valuable asset or cause the company to purchase its own shares. ${ }^{86}$ The Code prohibits such defensive tactics except where they have been approved by the shareholders. ${ }^{87}$

As a second facilitating measure, the Code provides a set of balanced rules for playing the takeovers game. Good rules facilitate takeovers, as well as other commercial transactions, by providing a generally acceptable and cost effective structure for a majority of deals. The internationalisation of the securities markets over the past two decades has been accompanied by increasing standardisation of securities and companies law. The draft Code adopts the principal rules of that international standard while avoiding some of the regulatory excesses. Both passive and active investors from any of the industrialised market economies would feel at home with the Code's rules respecting, eg, takeovers procedure, disclosure, equal treatment and use of conditions.

It is important to note that the list of takeover techniques favoured in current practice does not include a general offer to all shareholders. General offers are ones made under the Companies Amendment Act 1963. In the two-year period studied by the Panel, there were only thirteen general offers made in respect of companies that would have been subject to the Code. In seven cases, the offers were made by persons already in de facto or legal control. Their objective was to consolidate that control, usually with a view to privatising the company under section 208 of the Companies Act 1955. In five cases the bidder was seeking control; in two of these, the incumbent de facto controller thwarted the takeover by means of a market stand; in the other three cases, the general offer was still open at the time of the Panel's report. ${ }^{88}$ In short, during the two year period, the general offer was not successfully employed to shift control of a single listed company. The paucity of general

84 See 17 CFR 240.14d-7 [withdrawal right]; on the duty of the target directors to promote an auction, see Mills Acquisition Co v McMillan Inc 559 A 2d 1261 (Del 1989).

85 See above $\mathrm{n} 61$ and accompanying text.

86 See Baigent v DMcL Wallace (1984) 2 NZCLC 99122 (sale of asset) and Howard Smith Ltd v Ampol Petroleum Ltd [1974] AC 821 (issue of shares). Purchase of own shares, now permitted by the Companies Act 1993, is a favoured defensive tactic in the USA. See Revlon Inc v MacAndrews $\mathcal{E}$ Forbes Holdings Inc 506 A 2d 173 (Del 1986). Rule 20. See Report of the Panel on the Takeovers Code (8 June 1995) Appendix B(II). 
offers for control, as compared to the USA, is a consequence of the concentrated holdings of shares in listed companies and the advantage enjoyed by de facto controllers. The draft Code will increase the number of general offers, as the general offer will be the primary alternative acquisition vehicle where shareholder approval is not forthcoming. Further, as described earlier, the fundamental rule combined with the restriction on market purchases will make susceptible to general offers the some 69 companies that are presently under de facto control.

The rules for general offers under the Code largely follow current practice under the Companies Amendment Act 1963. However, the bidder may not take up any securities unless it obtains acceptances sufficient to give it legal control. ${ }^{89}$ Opponents of the Code argue that this $50 \%$ acceptance condition will increase the cost of a takeover. However, when its operation is analysed in the context of the local market, the acceptance condition will not significantly increase the cost of general offers as compared to existing practice. At present, although not required by law, general offers for control usually carry a $50 \%$ minimum acceptance condition as such a condition in the interests of the bidder and offeree shareholders.

The further cost effects of the minimum acceptance condition will depend upon the circumstances of the particular case. Where the offeror and its financial backers are confident of their ability to manage the business profitably, the condition will not increase the net cost of the takeover. This is so because the cost of any additional shares can be financed out of the distributions generated by the shares. Nor will the general offer requirement increase the cost of a takeover where legal control rests with a single person who is confident of the acquirer's ability to manage the business. In this event, the existing controller will be willing to sell into a general offer, even one with a $51 \%$ minimum acceptance condition. The general offer requirement and minimum acceptance condition will prevent a takeover only where the target shareholders, the bidder's financial backers and any existing block holder have doubts about the economics of the transaction. However, these are exactly the kind of takeovers that the law should probably deter. ${ }^{90}$

In summary, the opponents' prediction concerning the cost effect of the draft Code is not supported by analysis. For the many companies under de facto or majority control, valueenhancing transfers can be implemented with shareholder approval, a cost effective monitoring device. The restriction on market purchases will make possible hostile takeovers in relation to almost half of the listed companies. Takeovers will be further facilitated by the prohibition of defensive tactics. The Code will increase the cost of some

89 Rule 11.

90 Andrews "The Stockholder's Right to Equal Opportunity in the Sale of Shares" (1965) 78 Harvard L Rev 505. 
transactions, notably pass the parcel schemes where shareholder approval is not forthcoming and general offers where the $50 \%$ minimum acceptance condition is viewed as an unacceptable cost constraint. However, as these are generally transactions of dubious economic merit, they should not be facilitated by a takeovers code.

\section{$V$ The Code will lead to a reduction in Share Prices}

In addressing the impact of the Code on the individual shareholder, opponents argue that the adoption of the Code will result in a reduction of share prices for both block holders and public shareholders. ${ }^{91}$ They would probably support this prediction along the following lines. The value of a large holding will be reduced, as the Code prevents the owner from capturing any control premium associated with the block. The value of small holdings will suffer as the Code, by increasing the cost and reducing the frequency of takeovers, will shave that component of the price which impounds the possibility of a takeover and the associated $20 \%$ to $40 \%$ premium.

The predicted impact on the price of publicly held shares is defensible in the USA market. As takeovers there are generally effected by means of a full cash offer, share prices may well impound the premium associated with a possible takeover. ${ }^{92}$ A rule that prevents takeovers will, ceteris paribus, remove that premium and result in a lower share price. In New Zealand, however, takeovers are generally effected by block trades without participation by public shareholders. ${ }^{93}$ The bulk of any premium is captured by block holders. The market price, though it may rise at the time of the block acquisition, does not generally remain elevated for any length of time. In this market, it is quite unlikely that public share prices impound a takeover premium. As the Code provides for increased participation by public shareholders, it is reasonable to expect that its adoption will result in a general increase in share prices.

As evidence for the predicted price impact, opponents of the Code point to studies of share prices in USA jurisdictions that have adopted anti-takeover provisions in their companies legislation. Some of these studies show that enactment of the legislation is accompanied by a drop in the share price of firms incorporated in the jurisdiction and, further, that an individual firm's share price recovers when, where permitted, the firm opts out of the statutory regime. The opponents of the Code leave the impression that there is no evidence to the contrary.

91 See "Call to Reject Takeovers Code" The Dominion 3 July 1995, 10.

92 A review of the 14d-1 filings on the ACQUIS file in the COMPANY library on LEXIS (Meaddata Corp) shows that, of the 63 tender offers registered under the Securities Exchange Act 1934 in the period October 1994 to May 1995, 90\% were full, single price cash offers.

93 See Report of the Panel on the Takeovers Code (8 June 1995) 3 and Appendix B. 
In fact, the evidence is very much divided. The most satisfactory studies are probably those which conclude that the price effect depends upon the type of anti-takeover measure. Fair price rules (like those in the Code) have little or no positive effect on share prices while certain statutory poison pills have a negative one. ${ }^{94}$ However, the net effect is positive as any fall in share price is more than offset by the increased takeover premiums received in relation to shares subject to these measures. ${ }^{95}$

The effect of the Code on the value of block holdings is subject to different considerations. In both New Zealand and the USA, large blocks are traded off market and often at a substantial premium. I was unable to locate any USA study on the effect of takeover rules on block trades or block prices. This is hardly surprising. Due to the defused ownership of shares in the USA, takeovers generally involve full cash offers. ${ }^{96}$

In my view, one must concede that the Code may result in some decrease in the value of large holdings due to its indirect constraint upon their alienation. Under the Code, the owner of more than $20 \%$ of the shares in a company can dispose of its entire block to a single purchaser only with shareholder approval or by acceptance of a full offer. This constraint comprises the vehicle for the increased participation rights afforded by the Code to public shareholders. The associated reduction in the value of the block is the trade-off for the likely positive effect upon the price of publicly traded shares. Critics tend to exaggerate both the significance and likely extent of the loss in value.

The fact that a legal rule impacts negatively upon the value of large holdings implies little or nothing about the social or economic utility of the rule. For example, the value of large holdings is probably also affected by the Stock Exchange's rules respecting related party transactions and by the rules in the new Companies Act for major transactions, minority buyouts and amalgamations. Some leading economists view these rules as efficient monitoring devices. ${ }^{97}$

The critics also assume that the premium paid for a large holding indicates that the disposition is a value-creating transaction. The premium supposedly comprises a share of the anticipated increase in the value of the target company resulting from the synergy, increased monitoring or management expertise provided by the purchaser. However, as described earlier, this assumption oversimplifies reality. There are at least seven possible

94 Jarrell and Poulsen Shark Repellants and Share Prices (1987) 19 J Fin Econ 127.

95 See Comment and Schwert "Evidence on the Deterrence and Wealth Effects of Modern Antitakeover Measures" (1995) 39 J Fin Econ 3.

96 See above $\mathbf{n} 92$.

97 See F Easterbrook and D Fischel The Economic Structure of Corporate Law (Harvard University Press, Cambridge, 1991) 79-81. 
explanations for the premium. ${ }^{98}$ In general, the premium can reflect superior information about the value of the target, an anticipated increase in profits from improved management or the anticipated extraction of non-shareholder benefits.

The one empirical study of the premia associated with block trades concludes that the least likely explanation is that the premium reflects an anticipated increase in dividends or capital growth associated with synergy or superior management. ${ }^{99}$ Increased dividends and capital growth attach to all shares equally. In an efficient market, these benefits will be impounded in the market price of the shares and command no separate premium in a block trade. On the empirical evidence, the most likely explanation is that the premium represents anticipated non-shareholder benefits, ie, extracted through favourable transactions between the company and the controlling shareholder. This study confirms the intuition and concerns which, historically, have driven the company law constraints on self-interest transactions and the listing requirements on related party transactions. It provides support for the Code's constraint upon block dispositions, ie, the requirement for shareholder approval either in the form of an affirmative vote or acceptance of an offer.

Finally, under the Code, it remains possible for the block holder to capture all or part of the premium. The block holder is free to capture any premium associated with up to $20 \%$ of the voting rights. Where the change of control is economically defensible, the block holder and prospective acquirer will usually be able to obtain shareholder approval. Alternatively, the block holder can sell into a full or partial offer and the acquirer is free to sell down any excess shares.

In summary, the predicted impact of the Code upon the value of shares seriously misapprehends the operation of the Code in the New Zealand market. On the available evidence, adoption of the Code will likely impact positively upon the value of publicly traded shares. Whilst there may be a negative impact on the value of large blocks, this has its own efficiency justification and represents the trade off for the benefits conferred upon public shareholders.

\section{The Code is Unnecessary}

Opponents challenge the need for the Code on two fronts. On the one hand, they deny that takeovers result in any abuses. This is consistent with their view that takeovers are economic, value-enhancing transactions. They acknowledge the problem of "looting" but, quite correctly, attribute that abuse to the misuse of control rather than the acquisition of control. On the other hand, they argue that any problems associated with takeovers,

98 See above nn 64-69 and accompanying text.

99 Barclay and Holderness "Private Benefits from Control of Public Corporations" (1989) 25 J Fin Econ 371. 
including looting, can be adequately dealt with by the new companies statute and listing requirements. ${ }^{100}$ This argument was accepted by the Government as the basis for its decision to defer action on the Code. This is somewhat ironic as, of all the criticisms of the Code, this one is probably least well-founded.

The Takeovers Act 1993 itself, in the specification of objectives and measures to be considered by the Panel, anticipates the principal abuses perceived to be associated with takeovers. These include -

- Coercion. There are a variety of offer tactics - eg, two tiered offers, short offer periods and inadequate information - that have a coercive effect.

- Unfair treatment. Public shareholders have no opportunity to participate equally in the majority of takeovers.

- Uneconomic transfers of control. Some takeovers are uneconomic in that they destroy or merely transfer value rather than create value.

- Uninformed market. In negotiated transactions, outside investors often know nothing about the plans of the acquirer.

- Involuntary investment. After a takeover, shareholders can find themselves in a company that is very different from the one in which they originally invested.

- Defensive tactics. Target directors use various measures to thwart an offer and deny shareholders the benefits of a transfer of control.

These perceived abuses are the subject of a rich body of academic literature, provoke a stream of complaints to regulatory authorities and provide a staple diet for financial journalists. In New Zealand, some of these abuses are aggravated by peculiarities in the market. In the USA, where holdings in listed companies are highly dispersed, it is difficult for an outsider to seize control without making a full cash offer accompanied by considerable publicity. In New Zealand, due to the concentration of holdings in listed companies, control is usually transferred by private treaty without any involvement by the public shareholders. With no opportunity to participate, public shareholders may feel uninformed and locked in after the event.

As a matter of first principles, it is not reasonable to suppose that the abuses associated with takeovers can be adequately regulated by the company law and the listing requirements. These two regimes, in both their traditional and contemporary forms, address

100 See Submission to the Takeovers Panel Advisory Committee on the Draft Takeovers Code (Business Roundtable, Wellington, June 1963) 6 ["We do not know what 'ills' the Code seeks to remedy."], 19 [fear of looting as motivation for mandatory offer rule], 37-41 [Listing Rules and Companies Act 1993 as adequate safeguards]. 
primarily corporate transactions, ie, ones to which the company is a party. A takeover is a securities transaction, one to which the company is not a party and therefore outside the traditional scope of company law. To fill this regulatory gap, all Anglo-American jurisdictions including New Zealand, have amended their securities law to include a regime for takeovers.

As regards the specific abuses, only two can be addressed, and then only imperfectly, by the rules of the Companies Act 1993. The general statutory duties of directors impose, at least in theory, a constraint upon defensive tactics and looting. However, as demonstrated by experience both here and abroad, these general duties have proven to be an ineffective regulatory device. They have no agreed meaning as applied to takeovers, apply only after the event and are notoriously expensive to enforce. In the USA, the progress of takeovers is frequently interrupted by litigation of these duties.

The new Listing Rules address all of the abuses commonly associated with takeovers. However, listing rules suffer from limitations on their scope and enforceability. Applicable only to listed companies, the Rules provide no protection for the shareholders in the larger unlisted companies in New Zealand. In contrast, the draft Code extends to unlisted companies having at least 50 members and $\$ 20$ million in assets. As described earlier, it is quite unlikely that the minority veto regime, the principal vehicle for fair treatment of shareholders, will ever apply to more than a handful of listed companies. Finally, as the Rules only have the force of contract between the Exchange and a listed company, it is difficult to devise a sanction for breach that does not also adversely effect the aggrieved shareholders.

The Code addresses each of the six abuses associated with takeovers with a composite of rules quite unlike those found in the companies statute or the listing requirements. The Code effectively discriminates between economic and uneconomic transfers of control. A proposed takeover that holds out the prospect of increased profits can proceed with shareholder approval or by way of a Code offer. The Code facilitates the use of general offers in that it prohibits defensive tactics, increases the contestability of a significant number of listed companies and provides a streamlined procedure. The Code will block a proposed change of control only if the target shareholders are unwilling to approve the transaction and the bidder is unwilling to make a general offer. The concurrence of these two conditions is strong evidence that there is something amiss with the proposed transfer of control.

The Code provides for fair treatment of shareholders in that it enables them to participate in a transfer of control either by voting on the transaction or accepting an offer for their shares. This is comparable to the position that shareholders enjoy under the Companies Act 1993 in relation to control transfers that are effected by a merger or an asset acquisition. The fundamental rule and pause and publicity requirements force information 
into the market. A block holder can dispose of its entire holding only by acceptance of a Code offer or with shareholder approval, both of which entail extensive disclosure.

The Code significantly reduces the involuntary aspects associated with takeovers. In relation to most transfers of control, the Code entitles shareholders to vote on the transaction or receive an offer for their shares. The Code entitles minority shareholders to a buyout right in the event that $90 \%$ or more of the shares come to be held by a single person. Unless authorised by the shareholders, the directors of the target company may not undertake measures that could thwart a takeover. The Code also restricts the ability of de facto controllers to defeat a hostile bid for control by means of on-market purchases. The pause and publicity requirements as well as the equal price rule preclude use of the most common types of offer tactics that are perceived to be coercive.

The main trade-off for these protections are the constraints imposed upon persons who hold or control more than $20 \%$ of the votes in companies subject to the Code. If these persons wish to dispose of more than $20 \%$, they must do so by acceptance to a Code offer, with shareholder approval or under an exemption of the Panel. As of February 1995, in 142 listed companies there were 86 parcels in the $20 \%$ to $50 \%$ range. As of that same date, there were over one million parcels smaller than $5 \%$ which will benefit from the protections of the Code.

\section{Conclusion}

The Government's decision to defer action on the draft Code leaves New Zealand as one of the few market economies without a modern takeovers regime. It is probably fair to attribute the decision, in large part, to the "law and economics" opposition to takeovers regulation and the Code. As this opposition was a minority position in the public submissions on the Code, one might expect the arguments to be particularly lucid and compelling. However, as this article has attempted to show, both the law component and the economics component were flawed.

The legal component of the argument, ie, that the Code is unnecessary in view of the companies statute and listing requirements, ignores the collective insight shared by lawmakers in most Western economies that takeovers regimes fill a regulatory gap. The Code affords shareholders protection comparable to that which they enjoy in relation to transfers of control effected by means of mergers and asset acquisitions. It addresses a variety of perceived abuses associated with changes of corporate control.

As the principal economics component of the argument, the Code is criticised on the ground that it will raise the costs of takeovers. This prediction results from a failure to observe the fundamental precept of the law and economics discipline, viz, to consider the 
total effect of an arrangement. ${ }^{101}$ Like other conduct, some takeovers create value, some destroy value and others transfer value. As anticipated by the Act, the object of takeovers regulation is to facilitate economic takeovers and deter uneconomic ones. To this end, the Code increases the costs of some takeovers and reduces the costs of others by means of rules which have become a part of the securities law of most all Western market economies in Asia, Europe and North America. The rules have both fairness and efficiency justifications and enjoy widespread support in the legal, business and academic communities.

The significance of the Government's decision lies, I think, more in appearances than substance. Takeovers are probably the least common of corporate and securities transactions. The Panel could identify only 65 transactions in the previous two years that would be affected by the Code. The majority of these would have likely proceeded, without any significant structural change, under the Code. There are less than 100 parcels of shares in the $20 \%$ to $50 \%$ no-go zone established by the fundamental rule of the draft Code. There are over a million small parcels held by public investors for whom the appearances of equality and participation are important. Takeover codes are a concession to these concerns by knowledgeable investors and their advisors who can structure transactions profitably under almost any set of rules. If the experience with insider trading and company law is any guide, the Government's decision is not the last chapter in the debate over takeovers regulation.

The most important lesson of the takeover saga concerns the role of law and economics in the legislative and consultative processes. Law and economics arguments combine empirical evidence, assumptions and logic in such a way that predictions and recommendations tend to appear as incontrovertible statements of scientific fact. This is particularly so in the absence of informed debate. There was no rejoinder, along law and economics lines, from the proponents of regulation in New Zealand. The report of the Panel refers, only in passing, to the law and economics criticisms of the draft Code. This was not for want of relevant material. Today, one can find in the rich literature of law and economics well reasoned argument for and against most legislative proposals. This probably explains why, outside of New Zealand, the law and economics discipline remains confined largely to the classroom. In any informed debate, the law and economics arguments for and against a proposal largely neutralise each other and force the lawmaker to come to grips with underlying political and moral choices. ${ }^{102}$

101 Coase "The Problem of Social Cost" (1960) J Law \& Econ 1, 43.

102 Kennedy "Cost Benefit Analysis of Entitlement Problems: A Critique" (1981) 33 Stanford L Rev 387 